\title{
METODA PERSPEKTYWNA USUWANIA METALI CIĘŻKICH Z WÓD PODZIEMNYCH ZACHODNIEJ UKRAINY
}

\author{
Yuliia Trach ${ }^{\bowtie}$ \\ Educational and Scientific Institute of Construction and Architecture, National University of Water and Environmental \\ Engineering, Rivne
}

\begin{abstract}
STRESZCZENIE
Na Ukrainie największymi odbiorcami wód podziemnych jako źródła wody pitnej są mieszkańcy zachodniej części kraju. Ze względu na obecność stref pękania skał wodoodpornych w regionach hydrogeologicznych zachodniej Ukrainy skład fizykochemiczny wody nie jest stały i może ulegać zmianie, w szczególności w zakresie zawartości metali ciężkich. Przyczyną ich obecności w wodach podziemnych są oddziaływanie antropogeniczne oraz biologiczne ługowanie rud mineralnych. Metale ciężkie mogą migrować w dół i w górę oraz przenikać do warstw wodonośnych wody pitnej przez pęknięte strefy warstw wodoodpornych. Rudy mineralne występujące na terytorium zachodniej Ukrainy zawierają metale ciężkie, a zdecydowana większość z nich to siarczki. Są one utleniane przez grupę bakterii tionowych (pH 5-7), w wyniku czego stężenie siarczanu w wodzie wzrasta. Jednocześnie na zachodniej Ukrainie powszechnie występują glinokrzemiany (zeolity, tufy, bazalty i inne), które mogą być wykorzystane jako sorbent w technologii uzdatniania wody. W porównaniu z tradycyjnie stosowanym wapnem gaszonym przy wykorzystaniu glinokrzemianów wydajność usuwania metali ciężkich jest większa ze względu na to, że odbywa się za pomocą dwóch mechanizmów - wymiany jonowej i tworzenia wodorotlenków metali ciężkich.
\end{abstract}

Słowa kluczowe: woda podziemna, oczyszczanie wód, metale ciężkie, sorpcja, glinokrzemiany

\section{WSTĘP}

Wody podziemne, które są szeroko wykorzystywane do celów pitnych, stanowią integralną część zasobów wodnych Ukrainy. W porównaniu do wód powierzchniowych mają kilka zalet, ponieważ są zwykle lepszej jakości, są lepiej chronione przed zanieczyszczeniem i parowaniem oraz znacznie mniej zależne od sezonowych i długoterminowych zmian klimatu. Znaczna część wód podziemnych jest hydraulicznie połączona $\mathrm{z}$ wodami powierzchniowymi, powodując potencjalną utratę zasobów wód rzecznych podczas ich eksploatacji. Ponadto oznacza to, że zanieczyszczenia obecne w wodach powierzchniowych mogą przenikać do wód podziemnych.
Mapa wykorzystania wód podziemnych i powierzchniowych do celów pitnych przedstawiona jest na rysunku. Obszary hydrogeologiczne położone w zachodniej części Ukrainy są najbardziej eksploatowane. Mieszkańcy tamtejszych regionów administracyjnych zużywają wodę ze źródeł artezyjskich prowincji hydrogeologicznej złożonego regionu ukraińskich Karpat (hidroheotohiczna prowincija sktadczatoji oblasti Ukrajins 'kych Karpat), wołyńsko-podolskiego basenu artezyjskiego (Wotyno-Podilskyj artezians'kyj basejn) i regionu wód szczelinowych ukraińskiej tarczy (obtast' triszczynnych wod Ukrajins'koho szczyta).

Głównymi czynnikami wpływającymi na rozmieszczenie i warunki powstawania wód podziemnych są: klimat, ukształtowanie terenu, geomorfo- 


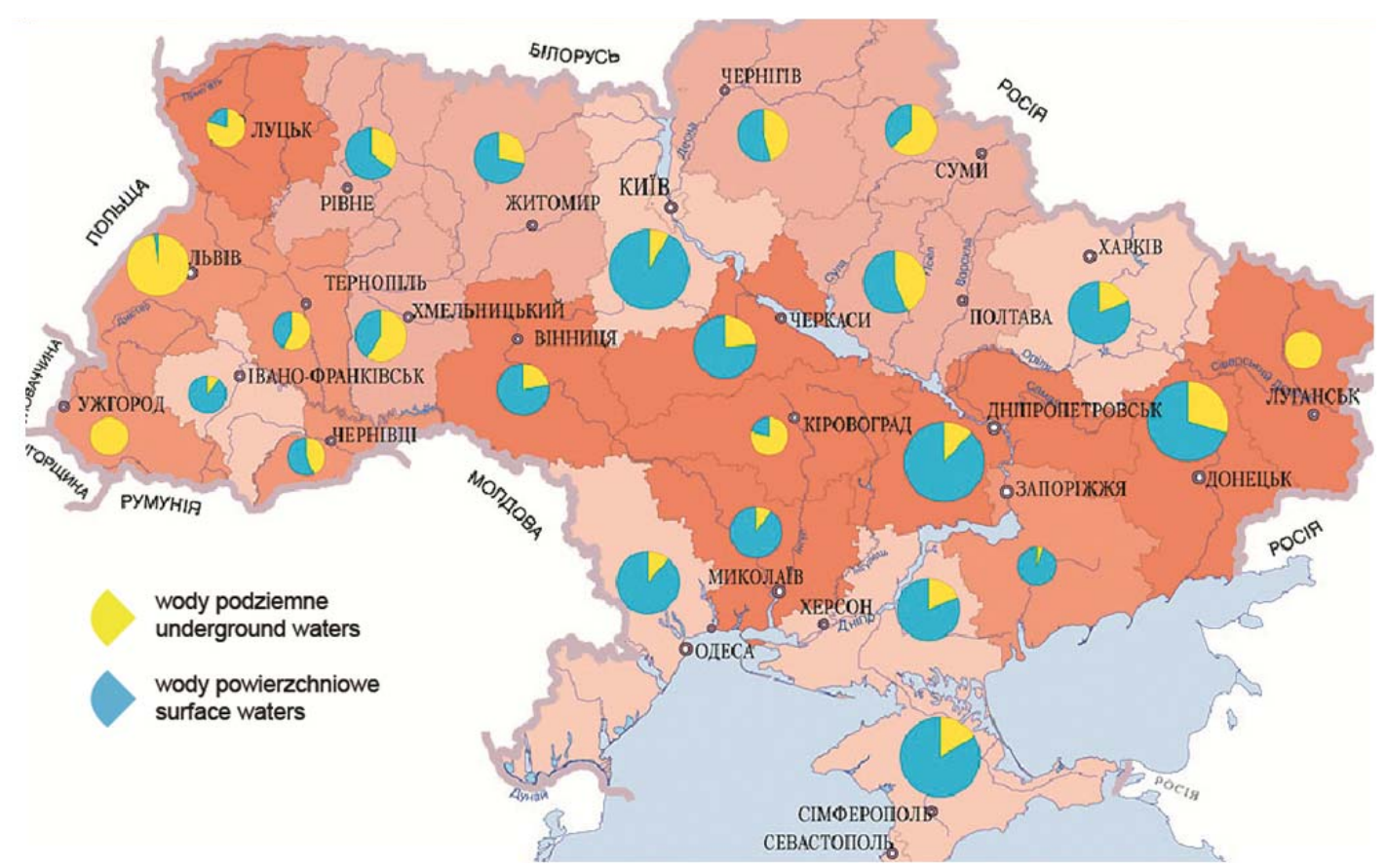

Rys. Mapa wykorzystania wód podziemnych i powierzchniowych do celów pitnych (Heonadra, 2018)

Fig. Map of the use underground and surface waters for drinking purposes (Heonadra, 2018)

logia, hydrografia, gleba i roślinność. Skład fizykochemiczny wód podziemnych zależy od ich zasilania i rozprzestrzeniania się stref pękania (Krainov i Shvets, 2012).

Do celów pitnych mieszkańcy zachodniej Ukrainy wykorzystują wodę z warstw wodonośnych międzywarstwowych, które są izolowane od wód gruntowych i od siebie nawzajem, ale obecność stref szczelin przyczynia się do migracji zanieczyszczeń. Wołyńsko-podolskie dorzecze artezyjskie ma dobrze rozwinięty system warstw wodonośnych, które praktycznie nie są od siebie oddzielone i tworzą jedną warstwę wodonośną. W basenie występują nieciągłości regionalne. Wynika to z pękania skał $\mathrm{w}$ warstwie osadowej i jest naturalnym czynnikiem negatywnym, który sprawia, że pobór wody zależy od migracji zanieczyszczeń $\mathrm{z}$ wód gruntowych.

Prawie wszystkie miasta znajdujące się na terytorium tarczy ukraińskiej wykorzystują warstwę wodonośną strefy pęknięć skał krystalicznych do zaopatrzenia $\mathrm{w}$ wodę. Warunki hydrogeologiczne akumulacji i cyrkulacji wód podziemnych w tym basenie są niekorzystne dla tworzenia się dużych zasobów wodnych. Nawadnianie warstw wodonośnych w obszarze i na głębokości jest wyjątkowo nierówne. Wody podziemne znajdują się w strefie szczelin krystalicznych skał prekambru oraz w osadach. Najwyższe szczeliny i wodospady skał krystalicznych można prześledzić na głębokości 70-150 m. Wody podziemne północno-zachodniej części tarczy ukraińskiej to wody typu wodorowęglan-wapń lub wodorowęglan-wapń-magnez, a ich mineralizacja nie przekracza $0,5 \mathrm{~g} \cdot \mathrm{dm}^{-3}$ (Krainov i Shvets, 2012).

Złożony region ukraińskich Karpat składa się $\mathrm{z}$ trzech różnych części i znajduje się w złożach fliszowych kredy i paleogenu. Wody na tym terenie są zwykle wodorowęglanowo-wapniowe i wodorowęglanowo-wapniowo-magnezowe, a ich mineralizacja wynosi od $0,1 \mathrm{do} 0,5 \mathrm{~g} \cdot \mathrm{dm}^{-3}$ (Krainov i Shvets, 2012; Shestopalov, Stetsenko i Rudenko, 2018). Według laboratorium hydrochemicznego Instytutu Nauk Geologicznych Akademii Nauk Ukrainy (Sukhorebry, 1986) porowatość wodoodpornych skał paleogenowych i kredowych wynosi 0,11-0,39 (średnio 0,20). 
Ze względu na obecność stref pękania skał wodoodpornych w regionach hydrogeologicznych zachodniej Ukrainy skład fizykochemiczny wód podziemnych nie jest stały i może ulegać zmianie. Na przykład metale ciężkie na dużych głębokościach w warunkach redukcyjnych (niski potencjał redoks) mogą być uwalniane, a $\mathrm{z}$ powodu zmiany temperatury wody mogą one migrować do góry.

\section{ANTROPOGENICZNE I NATURALNE PRZYCZYNY OBECNOŚCI METALI CIĘŻKICH W WODACH PODZIEMNYCH}

Metale ciężkie są jednym z najniebezpieczniejszych zanieczyszczeń wód podziemnych wykorzystywanych do celów pitnych. Źródłem ich obecności w wodach naturalnych jest wpływ człowieka i naturalne procesy biologicznego ługowania rud mineralnych. Takiej wody nie należy używać do celów pitnych bez uprzedniego oczyszczenia.

Toksyczne dla ludzi metale ciężkie, których stężenia przekracza państwowe normy i przepisy sanitarne (DSanPIN 2.2.4-171-10), są podzielone na biogenne i niebiogenne (Brindja i Grubinko, 2014).

Biogennymi metalami ciężkimi są metale, które są niezbędne do prawidłowego rozwoju oraz funkcjonowania flory i fauny $\mathrm{w}$ takim lub innym stężeniu, np.: $\mathrm{Fe}^{3+}, \mathrm{Mn}^{2+}, \mathrm{Zn}^{2+}, \mathrm{Co}^{2+}, \mathrm{Mo}^{2+}, \mathrm{Cr}^{3+}$. Aktywność, wzrost i rozwój żywych organizmów zależy od pory roku. Największa taka aktywność, a potem spożycie składników odżywczych, w tym wymienionych wcześniej metalach ciężkich, występuje wiosną. W związku $\mathrm{z}$ tym stężenie biogenicznych metali ciężkich w wodach gruntowych i podziemnych jest zmienne oraz zależy od pory roku.

Do niebiogennych metali ciężkich, które mogą występować $\mathrm{w}$ wodach gruntowych i podziemnych, należą m.in. $\mathrm{Pb}^{2+}, \mathrm{Cd}^{2+}, \mathrm{Ni}^{2+}, \mathrm{Hg}^{2+}$. Metale te są toksyczne dla żywych organizmów, a ich zawartość w wodzie nie zależy od sezonowej aktywności biologicznej. Ich obecność zależy głównie od działalności człowieka. Dostają się wód podziemnych i gruntowych wczesną wiosną, w połowie lata i wczesną jesienią, a ich migracja wiąże się z opadami deszczu i odwilżą (Brindja i Grubinko, 2014). Zawartość metali ciężkich w wo- dach podziemnych jest więc zmienna, a także zależy od pory roku i sposobu użytkowania gleb.

Naturalną drogą przedostawania się metali ciężkich do wód podziemnych jest proces chemicznego rozpuszczania minerałów endogennych (np. galeny) i egzogennych (np. anglezyt, cerusyt). Obecność niklu w naturalnych wodach jest spowodowana składem skał, przez które przepływa woda: występuje w złożach rud siarczkowych miedziowo-niklowych i rud żelazowo-niklowych. Stężenie niklu wzrasta niekiedy nawet do $20 \mathrm{mg} \cdot \mathrm{dm}^{-3} \mathrm{w}$ wodach podziemnych przepływających przez skały zawierające ten pierwiastek (Grinchenko i in., 2006).

Biologicznym źródłem metali ciężkich w wodach podziemnych jest biologiczne lugowanie minerałów. Rozpuszczanie metali ciężkich do postaci jonowych następuje w wyniku aktywności bakterii żyjących na powierzchni rud zawierających mineralne związki metali (Musich Demikhov, 2014). Naturalny proces ługowania biologicznego może zachodzić w wyniku wysokokwasowego utleniania siarczków metali oraz metabolitów żywych kultur mikroorganizmów. Według badań przeprowadzonych przez Narodową Akademię Nauk Ukrainy (Musich Demikhov, 2012) w strefach pękania zwietrzałej kory tarczy ukraińskiej bardzo często wykrywane są bakterie tionowe, które utleniają siarczki metali.

Wiadomo, że utlenianie minerałów siarczkowych przez bakterie kwasofilowe zachodzi przy $\mathrm{pH}$ 1,5-2 (Sidakina, 2005; Musich Demikhov, 2012). Jednak wyniki badań aktywności naturalnej mikroflory rudy siarczkowej niklu wykazały możliwość aktywnego bioługowania przez umiarkowanie kwasofilowe $(\mathrm{pH}$ 4) i neutrofilowe ( $\mathrm{pH} \mathrm{5-7)} \mathrm{bakterie} \mathrm{tionowe} \mathrm{Halothio-}$ bacillus halophilus (Musich Demikhov, 2014). Rola bakterii tionowych $\mathrm{w}$ procesie bioługowania polega na utlenianiu $\mathrm{Fe}^{2+}$ do $\mathrm{Fe}^{3+}$, utlenianiu siarki elementarnej oraz redukcji związków siarki i tworzeniu $\mathrm{H}_{2} \mathrm{SO}_{4}$. Pod wpływem powstałych jonów wodorowych takie minerały jak sfaleryt $(\mathrm{ZnS})$, chalkopiryt $\left(\mathrm{CuFeS}_{2}\right)$ i galena $(\mathrm{PbS})$ mogą ulegać rozpuszczaniu. W związku z powyższym skład chemiczny wód podziemnych pod względem metali ciężkich nie jest stabilny oraz zależy zarówno od obecności stref pękania, jak i od czynników naturalnych i antropogenicznych. 


\section{ISTNIEJACCE SPOSOBY USUWANIA METALI CIĘŻKICH Z WÓD PODZIEMNYCH}

Zmieniająca się zawartość metali ciężkich w wodach podziemnych utrudnia wybór technologii uzdatniania wody do celów pitnych. Opracowane technologie uzdatniania wody nie są w stanie skutecznie usunąć wszystkich metali ciężkich z wody. Do ich eliminowania stosuje się m.in. sorpcję, wymianę jonową, filtrację, koagulację i inne, jednak w praktyce do ich usuwania najczęściej stosuje się metodę odczynnikową.

W wodzie metale ciężkie mogą być rozpuszczalne tylko w środowisku kwaśnym, więc istotą metody odczynnikowej jest zwiększenie $\mathrm{pH}$ wody $(>7)$ w celu stworzenia warunków do powstawania nierozpuszczalnych faz metali. Do neutralizacji wód kwaśnych i tworzenia nierozpuszczalnych zasad metali ciężkich często używa się wapna gaszonego $\left(\mathrm{Ca}(\mathrm{OH})_{2}\right)$ - jest to najtańszy odczynnik, węglanu wapnia $\left(\mathrm{CaCO}_{3}\right)$, sody kalcynowanej $\left(\mathrm{Na}_{2} \mathrm{CO}_{3}\right)$, wapna palonego $(\mathrm{CaO})$ i wodorotlenku magnezu $\left(\mathrm{Mg}(\mathrm{OH})_{2}\right)$ (Masindi, 2016).

Pomimo niskiej ceny wapienia metoda ta ma kilka wad, z których główną jest mała prędkość reakcji między kwasem a cząstkami zawiesiny wapienia. Po zastosowaniu tej metody woda jest neutralizowana i zawiera wysokie stężenie jonów $\mathrm{Ca}^{2+}$, co może wymagać dalszego zmiękczenia. Alternatywą stosowania opisanych wcześniej odczynników do usuwania jonów metali ciężkich mogą być naturalne materiały zawierające glinokrzemiany. Mają one właściwości wymiany jonowej i nieznacznie modyfikują odczyn wody do neutralnego lub lekko zasadowego (Mel'nychuk, Trach, Kosinov, Mikhel' i Rechek, 2018; Trach, Kosinov, Mel'nychuk, Mikhel' i Reczek, 2018). Przy stosowaniu glinokrzemianów wydajność usuwania metali ciężkich w porównaniu $\mathrm{z}$ tradycyjnie stosowanym wapnem gaszonym jest większa ze względu na to, że odbywa się za pomocą dwóch mechanizmów - wymiany jonowej i tworzenia nierozpuszczalnych faz. W artykule wykorzystano naukową metodę analizy, a mianowicie podejście systemowo-aktywnościowe, które przed- stawione zostało $\mathrm{w}$ postaci logicznie powiązanego algorytmu ,potrzeba - przedmiot - procesy - wynik - bezpieczeństwo środowiska". W praktyce koncepcja ta została wdrożona $\mathrm{z}$ użyciem wymienionych dalej metod badawczych. Na początkowym etapie badań przeanalizowano współczesne osiągnięcia naukowe w danym kierunku. Kolejnym etapem badań jest teoretyczna analiza składu chemicznego rud mineralnych składowanych i wydobywanych na zachodniej Ukrainie. Na podstawie syntezy informacji naukowych otrzymane zostały odpowiednie wnioski.

\section{ZŁOŻA RUD MINERALNYCH ZAWIERAJĄCE METALE CIĘŻKIE W ZACHODNIEJ CZĘŚCI UKRAINY}

W zachodniej części Ukrainy większość złóż rud mineralnych, które zawieraja metale ciężkie, skoncentrowana jest w północnej i zachodniej części tarczy ukraińskiej. Sa to stosunkowo niewielkie złoża na obszarze hydrogeologicznym ukraińskich Karpat. Wyniki analizy współczesnych badań naukowych (Smirnov, 1995; Shcherbak i Bobrov, 2006), które dotyczą badania składu rud mineralnych zawierających metale ciężkie oraz ich rozmieszczenia w zachodniej Ukrainie, zestawiono $\mathrm{w}$ tabeli.

Analizując skład chemiczny szeroko rozpowszechnionych rud mineralnych w zachodniej części Ukrainy (tab.), można zauważyć, że zdecydowana większość z nich to siarczki metali ciężkich. Zatem $\mathrm{z}$ powodu bioługowania $\mathrm{w}$ wodach podziemnych obszaru badań mogą znajdować się różne metale ciężkie. Stężenie siarczanów w wodzie podziemnej jest często niezmienne. Oznacza to, iż wzrost stężenia siarczanów w wodzie podziemnej może sygnalizować o obecności w niej metali ciężkich.

Codzienne monitorowanie zawartości metali ciężkich w wodach podziemnych jest dość złożone i kosztowne $\mathrm{w}$ przeciwieństwie do analizy zawartości siarczanów. W celu wykrycia ewentualnego uwolnienia metali ciężkich wskazane jest więc kontrolowanie zawartości siarczanów w wodzie używanej do celów pitnych. 
Tabela. Obecność minerałów zawierających metale ciężkie w regionach administracyjnych i obszarach hydrologicznych zachodniej Ukrainy (Smirnov, 1995; Shcherbak i Bobrov, 2006)

Table. Presence of minerals containing heavy metals in administrative regions and hydrological areas western Ukraine (Smirnov, 1995; Shcherbak \& Bobrov, 2006)

\begin{tabular}{lccc}
\hline Metal & & Norma zawartości \\
ciężki & Minerał & Region administracyjny / & w wodzie pitnej* \\
Heavy & Minerals & Obszar hydrogeologiczny & Standard content \\
metal & & Administrative region / & in drinking water \\
& & / Hydrogeological area & {$\left[\mathrm{mg} \cdot \mathrm{dm}^{-3}\right]$}
\end{tabular}

\begin{tabular}{|c|c|c|c|}
\hline \multirow{2}{*}{$\mathrm{Cu}(\mathrm{II})$} & $\begin{array}{l}\text { chalkopiryt } \mathrm{CuFeS}_{2}(34 \%) \\
\text { bornit } \mathrm{Cu}_{5} \mathrm{FeS}_{4}(34 \%) \\
\text { chalkozyn } \mathrm{Cu}_{2} \mathrm{~S}(79,8 \%)\end{array}$ & $\begin{array}{l}\text { obwody: żytomierski, wołyński / tarcza ukraińska, } \\
\text { wołyńsko-podolski basen artezyjski }\end{array}$ & 1,0 \\
\hline & $\begin{array}{l}\text { chalkopyrite } \mathrm{CuFeS}_{2}(34 \%) \\
\text { bornite } \mathrm{Cu}_{5} \mathrm{FeS}_{4}(34 \%) \\
\text { chalcocite } \mathrm{Cu}_{2} \mathrm{~S}(79.8 \%)\end{array}$ & $\begin{array}{l}\text { districts (oblast): Zhytomyrska, Volynska / Ukrainian } \\
\text { Shield, Volhynian-Podolian Artesian Basin }\end{array}$ & 1.0 \\
\hline \multirow{2}{*}{ Co (II) } & $\begin{array}{l}\text { linneit } \mathrm{Co}_{3} \mathrm{~S}_{4}(53 \%) \\
\text { kobaltyn } \mathrm{CoAsS}(34 \%) \\
\text { smaltyn } \mathrm{CoAs}_{3-2}(20 \%)\end{array}$ & $\begin{array}{l}\text { obwody: żytomierski, wołyński, doniecki / tarcza } \\
\text { ukraińska, wołyńsko-podolski basen artezyjski }\end{array}$ & 0,1 \\
\hline & $\begin{array}{l}\text { linneite } \mathrm{Co}_{3} \mathrm{~S}_{4}(53 \%) \\
\text { cobaltite } \mathrm{CoAsS}(34 \%) \\
\text { smaltite } \mathrm{CoAs}_{3-2}(20 \%)\end{array}$ & $\begin{array}{l}\text { districts (oblast): Zhytomyrska, Volynska, Donetska / } \\
\text { / Ukrainian Shield, Volynian-Podolian Artesian Basin }\end{array}$ & 0.1 \\
\hline \multirow{2}{*}{ Ni (II) } & $\begin{array}{l}\text { pentlandyt }(\mathrm{Fe}, \mathrm{Ni})_{9} \mathrm{~S}_{8}(22-42 \%) \\
\text { milleryt } \mathrm{NiS}(65 \%) \\
\text { chloantyt }(\mathrm{Ni}, \mathrm{Co}) \mathrm{As}_{2} \\
\text { polidymit } \mathrm{Ni}_{3} \mathrm{~S}_{4}\end{array}$ & $\begin{array}{l}\text { obwody: północ równeńskiego, żytomierski, wołyński / } \\
\text { / tarcza ukraińska, wołyńsko-podolski basen artezyjski }\end{array}$ & 0,02 \\
\hline & $\begin{array}{l}\text { pentlandite }(\mathrm{Fe}, \mathrm{Ni})_{9} \mathrm{~S}_{8}(22-42 \%) \\
\text { millerite } \mathrm{NiS}(65 \%) \\
\text { chloanntite }(\mathrm{Ni}, \mathrm{Co}) \mathrm{As}_{2} \\
\text { polydymite } \mathrm{Ni}_{3} \mathrm{~S}_{4}\end{array}$ & $\begin{array}{l}\text { districts (oblast): north of Rivnenska, Zhytomyrska, } \\
\text { Volynska / Ukrainian Shield, Volhynian-Podolian } \\
\text { Artesian Basin }\end{array}$ & 0.02 \\
\hline \multirow[b]{2}{*}{$\mathrm{Pb}(\mathrm{II})$} & $\begin{array}{l}\text { galena } \mathrm{PbS}(86,6 \%) \\
\text { jamesonit } \mathrm{Pb}_{4} \mathrm{FeSb}_{6} \mathrm{~S}_{14}(50,8 \%)\end{array}$ & $\begin{array}{l}\text { obwody: równeński, lwowski, zakarpacki, chmielnicki / } \\
\text { / złożony region ukraińskich Karpat, tarcza ukraińska }\end{array}$ & 0,01 \\
\hline & $\begin{array}{l}\text { galena } \mathrm{PbS}(86.6 \%) \\
\text { jamesonite } \mathrm{Pb}_{4} \mathrm{FeSb}_{6} \mathrm{~S}_{14}(50.8 \%)\end{array}$ & $\begin{array}{l}\text { districts (oblast): Rivnenska, Lvivska, Zakarpatska, } \\
\text { Khmelnytska / folded region of the Ukrainian } \\
\text { Carpathians, Ukrainian Shield }\end{array}$ & 0.01 \\
\hline \multirow[b]{2}{*}{$\mathrm{Cd}$} & $\begin{array}{l}\text { grenokit CdS }(78 \%) \\
\text { wraz z rudami cynku i ołowiu }\end{array}$ & $\begin{array}{l}\text { obwody: lwowski, zakarpacki, równeński, chmielnicki / } \\
\text { / złożony region ukraińskich Karpat, tarcza ukraińska }\end{array}$ & 0,001 \\
\hline & $\begin{array}{l}\text { greenockite CdS }(78 \%) \\
\text { with zinc and lead ores }\end{array}$ & $\begin{array}{l}\text { districts (oblast): Lvivska, Zakarpatska, Rivnenska, } \\
\text { Khmelnytska / folded region of the Ukrainian } \\
\text { Carpathians, Ukrainian Shield }\end{array}$ & 0.001 \\
\hline \multirow[b]{2}{*}{ Zn (II) } & sfaleryt ZnS (67\% Zn) & $\begin{array}{l}\text { obwody: lwowski, zakarpacki, równeński, chmielnicki / } \\
\text { / złożony region ukraińskich Karpat, tarcza ukraińska }\end{array}$ & 1,0 \\
\hline & sphalerite $\mathrm{ZnS}(67 \% \mathrm{Zn})$ & $\begin{array}{l}\text { districts (oblast): Lvivska, Zakarpatska, Rivnenska, } \\
\text { Khmelnytska / folded region of the Ukrainian } \\
\text { Carpathians, Ukrainian Shield }\end{array}$ & 1.0 \\
\hline
\end{tabular}

* Według normy DSanPiN 2.2.4-171-10. Hihijeniczni wymohy do wody pytnoji, pryznaczeno - According to standard DSanPiN 2.2.4-171-10. Hygienic requirements for drinking water intended for human consumption. 


\section{CECHY STRUKTURY KRYSTALICZNEJ GLINOKRZEMIANÓW I ICH WŁAŚCIWOŚCI}

Naturalne materiały zawierające glinokrzemiany mogą być użyte do usuwania $\mathrm{z}$ wody metali ciężkich jako złoża filtrów lub sorbent. Zależy to od budowy krystalicznej samego glinokrzemianu, która determinuje jego specyficzne właściwości w wodzie.

Klasyfikacji naturalnych glinokrzemianów dokonuje się według stosunku glinu do krzemu: niski krzem Al : Si (alkaliczny) - $1: 1-1: 1,5$; średni krzem $\mathrm{Al}: \mathrm{Si}$ (średnie) - $1: 2$; wysoki krzem Al : Si (kwasowy) $-1: 3-1: 5$. Niszczenie minerałów rośnie wraz ze wzrostem roli aluminium koordynacyjnego w ich strukturach krystalicznych (Kornilovich, Andriyevska, Plemiannikov i Spasonova, 2013). Najbardziej aktywnym niszczycielem glinokrzemianów w wodzie jest jon $\mathrm{H}^{+}$, który ma właściwości akceptora elektronów i zdolność przenikania do sfery elektronowej kryształu, a mianowicie mostkuje tlen z tworzeniem związków Al-OH-Si, które w konsekwencji są dalej wydłużane i osłabiane.

Jony $\mathrm{H}_{3} \mathrm{O}^{+}$i $\mathrm{OH}^{-}$również są związane $\mathrm{z}$ niszczeniem struktury krystalicznej. Zwiększają koordynację krzemu i aluminium w krysztale i całkowicie przerywają związki mostkowe. Końcowymi produktami są $\mathrm{Si}(\mathrm{OH})_{4}$ i $\mathrm{Al}(\mathrm{OH})_{3}$, które wytrącają się w postaci koloidalnego osadu, pierwszy w postaci $\mathrm{SiO}_{2}-\mathrm{n}\left(\mathrm{H}_{2} \mathrm{O}\right)$ (Kornilovich i in., 2013). Z tego powodu glinokrzemiany o małej zawartości krzemu są bardzo niestabilne w środowisku kwaśnym i zasadowym, a ze względu na specyfikę struktury krystalicznej nie mogą być stosowane jako złoża filtrów do oczyszczania wód gruntowych z metali ciężkich, a jedynie jako sorbent.

Ze względu na odwracalność sorpcji jest ona najbardziej wydajnym ekonomiczne oraz wygodnym procesem. Sorpcja nie jest jednak skuteczna w bardzo stężonym roztworze, ponieważ adsorbent jest szybko nasycany metalami ciężkimi (Masindi, 2016). Ponadto naturalne materiały o właściwościach sorpcyjnych wykazują większą wydajność przy niskim poziomie mineralizacji wody.

Wiadomo, że metale ciężkie mogą być zawarte w wodzie o niskim $\mathrm{pH}$. W pracach Mel'nychuka i innych (2018) oraz Tracha i innych (2018) podano, że w wyniku kontaktu kwaśnej wody zawierającej metale ciężkie $\mathrm{z}$ tufami nastąpił wzrost $\mathrm{pH}$ wody i spadek potencjału redoks. Zmiana tych parametrów została wyjaśniona przez dysocjację jonowymiennych metali alkalicznych i metali ziem alkalicznych oraz glinokrzemianów, które są częścią tufów. Wzrost $\mathrm{pH}$ wody doprowadził do powstania czastek koloidalnych pochodzenia nieorganicznego. $\mathrm{W}$ rezultacie konieczne było oddzielenie oczyszczonej wody od nasyconego metali ciężkimi tufu i powstających cząstek koloidalnych.

Przy zastosowaniu w technologii uzdatniania wody takich materiałów jako sorbentu mieszanie wód podziemnych z sorbentem powinno odbywać się w specjalnym zbiorniku. Materiały naturalne ulegają całkowitemu wysyceniu metalami ciężkimi w ciagu 90-120 min (Bhattacharyya i Sen Gupta, 2006; Qi i in., 2016). W takim zbiorniku pewne utworzone zawiesiny koloidalne zostaną osadzone, ale nie wszystkie, dlatego woda po zastosowaniu glinokrzemianów powinna być uzdatniana na filtrze $z$ granulowanym materiałem filtracyjnym.

Ważną zaletą stosowania naturalnych materiałów glinokrzemianowych jest powszechność ich występowania w zachodniej części Ukrainy oraz to, że w kontakcie z wodą zmniejszają jej potencjał redoks (Mel'nychuk i in., 2018). Ma to pozytywny wpływ na jakość wody pitnej, ponieważ zwiększenie właściwości regenerujących wody pitnej wpływa korzystnie na mikroflorę przewodu pokarmowego, wzrost normalnej mikroflory (bifidobakterii i bakterii mlekowych) oraz thumienie patogenów chorobotwórczych i warunkowych (Goncharuk, Bagrii, Mel'nik, Chebotareva i Bashtan, 2010). $Z$ tego powodu wprowadzenie technologii oczyszczania wody, w tym wykorzystanie naturalnych materiałów zawierających glinokrzemiany jako sorbent, a następnie filtracja wody (w celu oddzielenia hydratów metalów ciężkich i zdyspergowanych cząstek materiału naturalnego od uzdatnionej wody) mogą być skutecznym rozwiązaniem w zakresie usuwania metali ciężkich z wód podziemnych używanych do celów pitnych.

\section{ROZPOWSZECHNIANIE MATERIAŁÓW GLINOKRZEMIANOWYCH W ZACHODNIEJ UKRAINIE}

Zachodnia część Ukrainy jest bogata w złoża naturalnych materiałów zawierających glinokrzemiany (zeolity, smektyty i inne). Takimi materiałami są np. tufy. 
Ułożone są one warstwami, tworząc powierzchnię okoto $200000 \mathrm{~km}^{2}$ (Pogribny, Lipchuk i Odnorozhenko, 2006; Mel'nychuk, Polishchuk i Mel'nychuk, 2007). Na powierzchni tufy pojawiają się $5 \mathrm{~km}$ na południowy wschód od miasta Sławuty w obwodzie chmielnickim (kamieniołom Taszky), w bazaltowych kamieniołomach w pobliżu wsi Berestowec, Mydsk, Basaltowo, Iwanicze (obwód równenski). Glinokrzemiany znajdują się również w bazaltach. Bazalty i czerwone tufy na równinach są nałożone warstwami. Znane złoże w Iwano-Dolinsku jest częścią dużego pola rozwoju, które obejmuje terytorium Podola, Wołynia, południowo-zachodniej Białorusi i południowo-wschodniej Polski. Bazalty i czerwone tufy rozciagają się w pasie o szerokości do $10 \mathrm{~km}$ na głębokościach od 5 do $250 \mathrm{~m}$ (Pogribny i in., 2006; Mel'nychuk i in., 2007).

\section{PODSUMOWANIE I WNIOSKI}

Obecność stref szczelin w skałach wodoodpornych sprzyja migracji w dół i w górę metali ciężkich oraz ich penetracji do warstw wodonośnych, z których woda wykorzystywana jest do celów pitnych przez mieszkańców zachodniej Ukrainy. Biologiczne ługowanie metali ciężkich ze źródeł naturalnych jest przyczyną ich obecności w wodzie podziemnej. Zaleca się monitorowanie siarczanów w wodach podziemnych, ponieważ wzrost ich stężenia może być oznaką obecności metali ciężkich w podwyższonych stężeniach. Wprowadzenie technologii oczyszczania wody, w tym wykorzystanie naturalnych materiałów zawierających glinokrzemiany jako sorbent, a następnie filtracja wody mogą być alternatywą tradycyjnie stosowanych metod uzdatniania i skutecznie rozwiązać problem podwyższonego stężenia różnych metali ciężkich w wodach podziemnych wykorzystywanych do celów pitnych. W przypadku Ukrainy rozwojowi tej technologii sprzyja wystepowanie rodzimych złóż materiałów zawierających glinokrzemiany.

\section{PIŚMIENNICTWO}

Bhattacharyya, K. G. i Sen Gupta, S. (2006). Pb(II) uptake by kaolinite and montmorillonite in aqueous medium: Influence of acid activation of the clays. Colloids and Surfaces A: Physicochemical and Engineering Aspects, 277, 191-200. doi: 10.1016/j.colsurfa.2005.11.060
Brindja, I. W. i Grubinko, W. W. (2014). Sezonna dynamika wmistu ważkych metaliw u wodi kołodiaziw na terytoriji prykarpattia [Seasonal dynamics of heavy metals content in wells in the Carpathian region]. Biolohichni systemy - Biological Systems, 6 (2), 197-204.

Derzhavna sluzhba heolohiyi ta nadr Ukrayiny [Heonadra] (2018). Stan pidzemnykh vod Ukrayiny. Kyiv.

DSanPiN 2.2.4-171-10. Hihijeniczni wymohy do wody pytnoji, pryznaczeno.

Goncharuk, V. V., Bagrii, V. A., Mel'nik, L. A., Chebotareva, R. D. i Bashtan, S. Yu. (2010). The use of redox potential in water treatment processes. Journal of Water Chemistry and Technology, 32 (6), 1-9. doi: 10.3103/ S1063455X10010017

Grinchenko, O. W., Kurilo, M. W., Mikhailov, W. A. i Mikhailova, L. Y., Ogar, W. W., Omelchuk, O.W., Shevchenko, W. I., Shunko, W. W., Sherbak, D. M. (2006). Metaliczni korysni kopałyny Ukrajiny. Kyiv: Vidavnicho-poligrafichnyy tsentr „Kyjivs'kyj universytet”.

Kornilovich, B. Y., Andriyevska, O. R., Plemiannikov, M. M. i Spasonova, L. M. (2013). Fizychna khimiya kremnezemu i nanodyspersnykh sylikativ. Kyiv: Osvita Ukrayiny.

Krainov, S. R. i Shvets, W. M. (2012). Geokhimiya podzemnykh vod. Moskva: CentrNefteGas.

Masindi, V. (2016). A novel technology for neutralizing acidity and attenuating toxic chemical species from acid mine drainage using cryptocrystalline magnesite tailings. Journal of Water Process Engineering, 10, 67-77.

Mel'nychuk, V. G., Polishchuk, A. M. i Mel'nychuk, G. V. (2007). Vulkanichni tufy v trapakh Volyno-Podillya yak al'ternativnyy ob'yekt dlya zakhoroneniya radioaktivnykh [Volcanic tuffs from the Volyn-Podillya ladder as an alternative material for the disposal of radioactive waste]. Visnyk Natsional'noho universytetu vodnoho hospodarstva ta pryrodokorystuvannya. Tekhnichni nauky, 5 (18), 107-113.

Mel'nychuk, V. G., Trach, Y. P., Kosinov, V. P., Mikhel', M. i Rechek, L. (2018). Doslidzhennya mineral'nono skladu i mozhlivostey vikoristannya disperkhovanikh bazal'tiv ta tufiv Ivanodolins'kogo rodovis' Rivnens'koi oblasti v galuzi vodooczis'enna vikoristannya [Research of the mineral complex and opportunities using basalts and tuffs of ivandodolinsky quarry of the Rivne region in the water treatment]. Problemy Vodopostachannya, Vodovidvedennya ta Hidravliky, 30, 36-47. doi: 10.32347/2524-0021.2018.30.36-47

Musich, E. G. i Demikhov, Y. M. (2012). Biovyshchelachivaniye metallov iz gornykhporod i otvalov: problemy i perspektivy [Bio-leaching of rocks and waste heaps: problems and prospects]. Zbirnyk naukovykh prats' In- 
stytutu Heokhimiyi Navkolyshn'oho Seredovyshchavypusk - Collected papers Institute of Environmental Geochemistry, 20, 120-124.

Musich, E. G. i Demikhov, Y. M. (2014). Biovyluhovuvannya yak praktychnyy pidkhid do ekstraktsiyi metaliv [Bioleaching as a Practical Approach to Metal Extraction]. Zbirnyk naukovykh prats'Instytutu Heokhimiyi Navkolyshn'oho Seredovyshcha - Proceedings of the Institute of Environmental Geochemistry, 23, 110-123.

Pogribny, V. T., Lipchuk, L. V. i Odnorozhenko, L. F. (2006). Anal'tsym-saponitovi horyzonty $\mathrm{v}$ rodovyshchakh mahniyevykh bentonitiv slavuta-izyaslavs'koyi ploshchi yak perspektyvni ob"yekty mineral'nykh sorbentiv bahatotsil'ovoho vykorystannya [Analcim-saponite horizons of magnesium bentonites of Slavutsko-Izyaslavskaya area as perspective objects mineral sorbents]. W Pershyy Vseukrayins'kyy z'yizd ekolohiv (ECOLOGY-2006). Zbirnyk materialiv Mizhnarodnoyi naukovopraktychnoyi konferentsiyi (strony 79-82). Vinnytsya: Universum.

Qi, S., Xue, Q., Niu, Z., Zhang, Y., Liu, F. i Chen, H. (2016). Investigation of $\mathrm{Zn}^{2+}$ and $\mathrm{Cd}^{2+}$ adsorption performance by different weathering basalts. Water Air Soil Pollution, 227, 126. doi: 10.1007/s11270-016-2800-8

Shcherbak, M. P. i Bobrov, O. B. (red.) (2006). Metallicheskiye i nemetallicheskiye poleznyye iskopayemyye Ukrainy. T. 1. Metallicheskiye poleznyye iskopayemyye. Kyiv - Lviv: Tsentr Yevropy.
Shestopalov, V. M., Stetsenko, B. D. i Rudenko, Y. F. (2018). Pidzemni vody trishchynuvatykh krystalichnykh porid yak rezervne dzherelo vodozabezpechennya vinnytsi (Ukrayina) [Groundwater of fractured cristalline rock as reserve source for potable water supply to Vinnitsa (Ukraine)]. Heolohichnyy zhurnal-Geological Journal, 1 (362), 5-16. doi: 10.30836/igs.1025-6814.2018.1.126414

Sidakina, G. G. (2005). Novyye ekologicheski chistyye tekhnologii $\mathrm{V}$ obogashchenii zolotosoderzhashchikh rud [New eco-friendly technologies in the enrichment of sulfide ores]. Stroitel'stvo i tekhnogennaya bezopasnost', 10, 169-173.

Smirnov, V. I. (1995). Heolohiya korysnykh kopaly. Kyiv: Vyshcha shkola.

Sukhorebry, A. A. (1986). Formirovaniye khimicheskogo sostava porovykh rastvorov platformennykh artezianskikh basseynov $\mathrm{v}$ zone intensivnogo vodoobmena [Formation of chemical composition of pore solutions of platform artesian basins in the zone of intensive water exchange]. Heolohichnyy zhurnal-Geological Journal, 4 (46), 96-105.

Trach, Y. P., Kosinov, V. P., Mel'nychuk, G. V., Mikhel', M. i Rechek, L. (2018). Vykorystannya saponitovykh tufiv v tekhnolohiyakh polipshennya yakosti pidzemnykh vod dlya pytnykh potreb [Using saponit in water treatment technology for drinking]. Visnyk Natsional'noho universytetu vodnoho hospodarstva ta pryrodokorystuvannya. Tekhnichni nauky, 2 (82), 210-221.

\title{
PERSPECTIVE METHOD FOR REMOVING HEAVY METALS FROM UNDERGROUND WATERS OF WESTERN UKRAINE
}

\begin{abstract}
The largest group of recipients of the drinking water from groundwater in Ukraine are resides in the western part of the country. Due to the presence of zones in which the water-resistant rocks are subject to cracking in the hydrogeological regions of the Western Ukraine, the physicochemical composition of water is not constant and may vary, especially in terms of heavy metals content. The reasons for the presence of heavy metals in the groundwater are the anthropogenic influence and biological leaching of mineral ores. Heavy metals can migrate up and down and penetrate the aquifers of drinking water through the cracked zones of the waterresistant rocks. The mineral ores found in the Western Ukraine contain heavy metals, mainly as sulfides. They

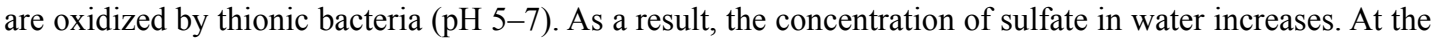
same time, in the Western Ukraine, natural materials containing aluminosilicates such as zeolites, tuffs, basalts and others are widely distributed. They can be used as sorbents in the process of groundwater treatment. When using aluminosilicates, the removal efficiency is higher than in the case of traditionally used slacked lime $\left(\mathrm{Ca}(\mathrm{OH})_{2}\right)$ due to the fact that heavy metals are extracted by means of two mechanisms - ion exchange and formation of insoluble bases.
\end{abstract}

Key words: groundwater, water treatment, heavy metals, sorption, aluminosilicates 